\title{
ELECTROPHORETIC CHANGES IN THE SERUM OF A PATIENT WITH RHEUMATOID ARTHRITIS
}

\author{
By VINCENT P. DOLE, AND SIDNEY ROTHBARD, wITH THE TECHNICAL ASSISTANCE OF \\ KENNETH WINFIELD
}

\author{
(From the Hospital of The Rockefeller Institute for Medical Research, New York)
}

(Received for publication August 8, 1946)

Various reports in recent years ( 1 to 5 ) have indicated that changes occur in the serum electrophoretic patterns of patients with rheumatoid arthritis. The present study is designed to supplement these generally isolated measurements with serial observations of the changing serum pattern through a cycle of the disease, correlated with immunological and clinical data. Of interest also is the comparison of data from this clinically typical case of rheumatoid arthritis with the data, previously reported (6), from patients with rheumatic fever of comparable severity and duration.

\section{METHODS}

All measurements, common to those of the earlier study (6), were made in the same way.

The antifibrinolysin antibody (AFL) was determined by the method of Tillett, Edwards and Garner (7), as modified by Boisvert (8).

The $\mathrm{C}$-reactive protein was measured by a modification of the method of Tillett and Francis (9): $0.1 \mathrm{ml}$. of undiluted test serum was mixed with $0.1 \mathrm{ml}$. solutions of the pneumococcus $C$ polysaccharide, ${ }^{1}$ varying in concentration downward from 10-4. After incubation at $37^{\circ} \mathrm{C}$. for 2 hours, the tubes were left overnight at $4^{\circ} \mathrm{C}$., then read for precipitation. A known strongly positive serum from a patient with acute rheumatic fever was included as a control.

\section{SUBJECT OF THE STUDY}

C. B. (No. 11, 113), a 28-year old machinist, was admitted to another hospital on the 8th day following the onset of polyarthritis. Prior to this, he had always enjoyed good health, and in particular had had no previous joint symptoms. The present attack was not preceded by any apparent respiratory infection. During a 2-month stay at that hospital, he had persistent painful swelling of an ankle, a knee and the small joints of the hands, not appreciably relieved by salicylates. An elbow had become involved shortly before admission.

When admited to the Rockefeller Hospital on the 64th day of illness he appeared chronicaly ill; his weight had fallen to $55 \mathrm{kgm}$. from a normal of about $72 \mathrm{kgm}$. Examination of the heart revealed no abnormalities either on admission or subsequently. There was definite atrophy of the muscles of the hands, both legs and one forearm.

\footnotetext{
1 Kindly supplied by Dr. Maclyn McCarty.
}

X-ray examination showed decalcification of the bones and periarticular swelling without narrowing of the joint spaces of the hands and knees. Cultures of nose and throat revealed no hemolytic streptococci, and the gonococcus complement fixation and Wassermann tests were both negative.

During 8 months of hospitalization he gradually improved under treatment with initial bed rest followed by slowly increased activity; hot packs to the affected joints with short periods of active exercise and plaster support as required were also employed. Aspiration of the right knee joint on the 248th day yielded $30 \mathrm{ml}$. of yellow, turbid and viscid fluid which contained 5,300 leuckocytes per c.m.m. (49 per cent polynuclear, 45 per cent lymphocyte, 6 per cent monocyte). The culture was negative.

At the time of discharge on the 332nd day, he was capable of doing light work; the only residual joint symptoms were slight swelling with limited flexion of one knee and weakness of one finger.

\section{OBSERVATIONS AND DISCUSSION}

The total protein concentration was not systematically affected. The relative proportion of albumin, and with it the $A / G$ ratio, was considerably depressed in the earlier observations, but later returned toward normal. Both $\alpha$ globulins were markedly elevated (over twice their normal values) during the early stages, then fell to essentially normal proportions. $\beta$ globulin was on the low side of normal throughout the study. $\gamma$ globulin maintained a fairly constant level about 35 per cent over the normal value.

These changes generally conform to those described by other authors ( 1 to 5 ), who have reported increases in the $a$ and $\gamma$ globulins, independently or in combination, and decreases in albumin.

A slight elevation above normal limits was observed in the titer of antistreptolysin O. According to other workers (10) such increases may occur in rheumatoid arthritis, but are exceptional. More typical of the disease is the absence of an antifibrinolysin response (11 to 13 ).

The $\mathrm{C}$-reactive protein is an interesting protein of unknown function that has been detected in the 


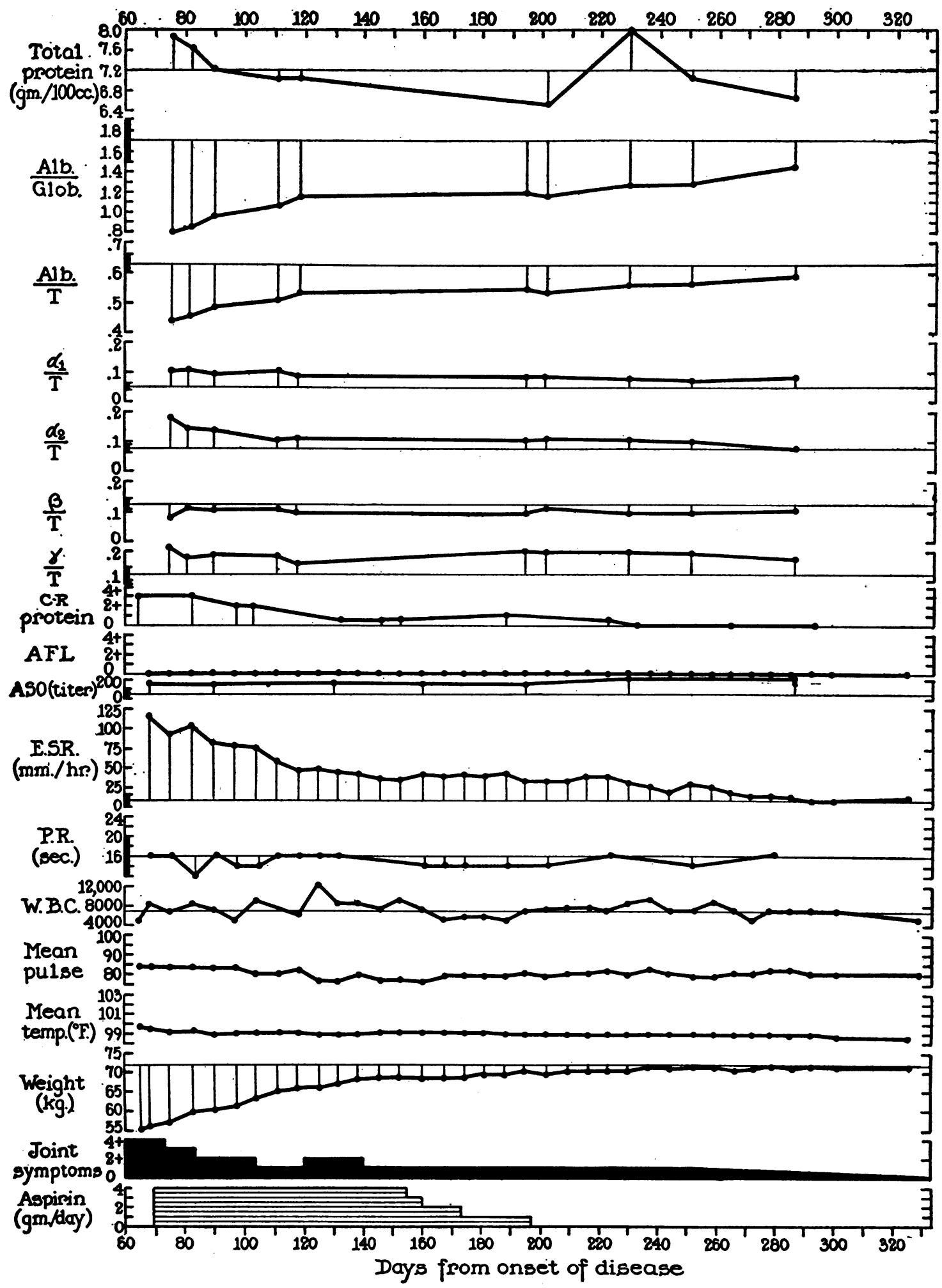


serum during the early phases of diverse infectious diseases $(14,15,9)$. It has not yet, however, been sufficiently studied to determine whether its appearance is confined to diseases of infectious etiology (16). The occurrence of this protein in association with increased $a$ globulins accords with the findings of previous workers (17) that it is contained in the $a_{1}$ globulin fraction.

As might be expected, the serum protein pattern varied with change in the clinical status; it is possible that a sufficiently extensive study might reveal correlations of prognostic significance. It is clear, on the other hand, that electrophoretic measurement holds no diagnostic promise, since the present findings appear to be indistinguishable from those previously reported for rheumatic fever (6).

\section{SUMMARY}

1. Serial electrophoretic observations of the serum from a patient with rheumatoid arthritis showed a depressed proportion of albumin with increased relative amounts of $a$ and $\gamma$ globulins.

2. These abnormalities in serum protein pattern decreased with clinical improvement.

3. Antistreptolysin $\mathrm{O}$ antibody titer showed a low constant elevation. Antifibrinolysin activity was not detectable.

4. The C-reactive protein, which was present in high titer during the early acute phase of the disease, disappeared with clinical recovery.

\section{BIBLIOGRAPHY}

1. Svartz, N., Nord. Med., 1943, 18, 673. $\}$ in Malmros, Nord. Med., 1944, 23, 1713. $\}$ H., and B. (4).

2. Olhagen, B., Om electroforese diagram pa plasma från homo vid patologiske tillstand. Nord. Med., 1944, 23, 1530.

3. Lövgren, O., Studien über den intermediären stoffwechsel bei chemischer polyarthritis. Acta Med. Scand., Suppl. 163, 1945

4. Malmros, H., and Blix, G., The plasma proteins in cases with high erythrocyte sedimentation rate. Acta Med. Scand., Suppl. 170, 1946.
5. Perlmann, Gertrude E., Kaufman, Dorothy, and Bauer, Walter., Electrophoretic distribution of proteins in serum, plasma and synovial fluid of patients with rheumatoid arthritis (to be published).

6. Dole, V. P., Watson, R. F., and Rothbard, S., Electrophoretic changes in the serum protein patterns of patients with scarlet fever and rheumatic fever. J. Clin. Invest., 1945, 24, 644.

7. Tillett, W. S., Edwards, L. B., and Garner, R. L., Fibrinolytic activity of hemolytic streptococci. The development of resistance to fibrinolysis following acute hemolytic streptococcus infections. J. Clin. Invest., 1934, 13, 47.

8. Boisvert, P. L., The streptococcal antifibrinolysin test in clinical use. J. Clin. Invest. 1940, 19, 65.

9. Tillett, W. S., and Francis, T., Jr., Serological reactions in pneumonia with a non-protein somatic fraction of pneumococcus. J. Exper. Med., 1930, 52, 561.

10. Bunim, J. J., and McEwen, C., The antistreptolysin titer in rheumatic fever, arthritis and other diseases. J. Clin. Invest., 1940, 19, 75.

11. Myers, W. K., Keefer, C. S., and Holmes, W. F., Jr., The resistance to fibrinolytic activity of the hemolytic streptococcus with special references to patients with rheumatic fever and rheumatoid (atrophic) arthritis. J. Clin. Invest., 1935, 14, 113.

12. McEwen, C., Bunim, J. J., and Alexander, R. C., Bacteriologic and immunologic studies in arthritis. II. Results of various immunologic tests in different forms of arthritis. J. Lab. and Clin. Med., 1935-36, 21, 465.

13. Perry, C. B., Streptococcal antifibrinolysin in rheumatoid arthritis and spondylitis anklylopoietica. Ann. of the Rheum. Dis., 1940-1941, 2, 147.

14. Ash, R., Nonspecific precipitins for pneumococcic fraction $C$ in acute infections. J. Infect. Dis., 1933, 53, 89.

15. Abernethy, I. J., and Avery, O. T., The occurrence during acute infections of a protein not normally present in the blood. I. Distribution of the reactive protein in patient's sera and the effect of calcium on the flocculation reaction with $\mathrm{C}$ polysaccharide of pneumococcus. J. Exper. Med., 1941, 73, 173.

16. Avery, O. T., and McCarty, M., Personal communication.

17. Perlman, E., Bullowa, J. G. M., and Goodkind, R., An immunological and electrophoretic comparison of the antibody to $C$ polysaccharide and the $C$ reactive protein of acute phase serum. J. Exper. Med., 1943, 77, 97. 